\title{
АКТИВІЗАЦІЯ ФІЗИЧНОЇ АКТИВНОСТІ ВИСОКОЇ ІНТЕНСИВНОСТІ ЧОЛОВІКІВ У ЛІТНІЙ ПЕРІОД СКЛАДОВИМИ СПОСОБУ ЖИТТЯ
}

\author{
Олесь Пришва ${ }^{1}$, Іван Глухов ${ }^{1}$, Микола Круглик ${ }^{2}$ \\ ${ }^{1}$ Херсонський державний університет, Херсон, Україна, оoobc@yahoo.com \\ ${ }^{2}$ Херсонська державна морська академія, Херсон, Україна \\ https://doi.org/10.29038/2220-7481-2019-04-61-67
}

\section{Анотації}

Aктуальність. Фізична активність високої та середньої інтенсивності - важлива складова частина здоров'я чоловіків молодого та середнього віку. На фоні тотального малорухомого способу життя активізація фізичної активності високої інтенсивності (ФАВІ) чоловіків доступними й природними засобами складників способу життя, що змінюють добовий енергетичний баланс, набуває актуальності, ураховуючи фактори сезонності. Мета дослідження - аналіз ефективності методу природної активізації ФАВІ чоловіків молодого й середнього віку корекцією енергетичного балансу організму в літній сезон. Методи дослідження. На першому етапі досліджували фізичний стан чоловіків, їх фізичну активність та харчування напередодні ФАВI; вираховували ІП співвідношення кількості пройдених кроків до кількості спожитих грамів їжі й відносної ваги спожитих продуктів тваринного та рослинного походження; отримані дані порівнювали з повсякденними показниками. Результатом стали індивідуальні моделі ІП з урахуванням відносної ваги спожитих тваринних і рослинних продуктів. На другому етапі експерименту чоловіки цілеспрямовано дотримувалися цих моделей, по закінченню порівнювали показники фізичного стану з початковими результатами. Результати. Основу експериментальних моделей констатувального експерименту становили відмінності між днями напередодні ФАВІ та звичайними: ІП - 44,58 \%, загальна фізична активність $-21,31 \%$, відносна вага тваринних продуктів - 14,65 \%, відносна вага рослинних продуктів - 10,62 \%, відносна вага спожитих продуктів - 10,04 \%. Основою моделі способу життя чоловіків у формувальному експерименті були індивідуальні IП - Me=1,66 кроків на грам спожитої їжі за добу, якого притримувалися чоловіки напередодні ФАВІ. Метод корекції енергетичного балансу чоловіків напередодні ФАВІ дав змогу збільшити кількість занять на тиждень ФАВI на 45,89 \%; кількість кроків ФАВІ - на 25,08 \%; затраченого часу занять - на $11,41 \%$. Позитивні зміни відзначено у фізичному стані чоловіків. Висновки. Розроблена методика природної активізації ФАВІ чоловіків складниками способу життя на основі моделювання добового енергетичного балансу організму, виявилась ефективною. Збільшення енергетичних запасів організму стимулює бажання занять ФАВІ наступного дня в літній період.

Ключові слова: спосіб життя чоловіків, фізична активність високої інтенсивності, модель харчування, інтегральний показник кількості кроків на грам їжі.

Олесь Пришва, Иван Глухов, Николай Круглик. Активизация физической активности высокой интенсивности мужчин в летний период составными образа жизни. Актуальность. Физическая активность высокой и средней интенсивности - важная составляющая здоровья мужчин молодого и среднего возраста. На фоне тотального малоподвижного образа жизни активизация физической активности высокой интенсивности (ФАВИ) мужчин доступными и естественными средствами составными образа жизни, меняющих суточный энергетический баланс, приобретает актуальность, с учетом фактора сезонности. Цель исследования - анализ эффективности метода естественной активизации ФАВИ мужчин молодого и среднего возраста коррекцией энергетического баланса организма в летний сезон. Методы исследования. На первом этапе исследовались физическое состояние мужчин, их физическая активность и питание накануне ФАВИ; высчитывались ИП соотношение количества пройденных шагов с количеством потребленных граммов пищи, так же относительного веса потребленных продуктов животного и растительного происхождения, данные сравнивались с повседневными показателями. Результатом стали индивидуальные модели ИП с учетом относительного веса животных и растительных продуктов. На втором этапе эксперимента мужчины целенаправленно придерживались данных моделей, по окончании сравнивались показатели физического состояния с начальными результатами. Результаты. Основу экспериментальных моделей составили различия между днями накануне ФАВИ и обычными: ИП - 44,58 \%, общая физическая активность $-21,31$ \%, относительный вес животных продуктов - 14,65 \%, относительный вес растительных продуктов - 10,62 \%, относительный вес всех продуктов - 10,04 \%. Основу модели образа жизни мужчин в формирующем эксперименте составили индивидуальные ИП с $M e-1,66$ шагов на грамм потребленной пищи за сутки, которого придерживались мужчины накануне ФАВИ. Метод коррекции энергетического баланса мужчин накануне ФАВИ позволил увеличить количество занятий в неделю ФАВИ на 45,89 \%; количество шагов ФАВИ - на 25,08 \%; затраченного времени занятий - на $11,41 \%$. Положительные изменения отмечались также в физическом состоянии мужчин. Выводы. Разработанная 
методика естественной активизации ФАВИ мужчин составными образа жизни на основе моделирования суточного энергетического баланса организма оказалась эффективной. Увеличение энергетических запасов организма в летний период стимулирует желание занятий ФАВИ на следующий день.

Ключевые слова: образ жизни мужчин, физическая активность высокой интенсивности, модель питания, интегральный показатель количества шагов на грамм пищи.

Oles Pryshva, Ivan Glukhov, Nikolay Kruglyk. Activation Vigorous Physical Activity of Men in the Summer Period by Lifestyles. Topicality. Vigorous and moderate physical activity is an important component of the health of young and middle-aged men. Against the backdrop of a total low-life lifestyle, the activation of vigorous physical activity (VPA) for men by accessible and natural lifestyle components that alter the daily energy balance becomes relevant, taking into account seasonality factors. The Purpose of the Research is to analyze the effectiveness of the method of natural activation of VPA in young and middle-aged men by correcting the energy balance of the body in the summer season. The Research Methods. At the first stage of the research, the physical condition of men, their physical activity and nutrition were examined on the eve of VPA; the IP calculated the ratio of the number of steps taken to the amount of consumed food grams and the relative weight of the consumed products of animal and vegetable origin; the obtained data were compared with the daily indicators. The result was the individual models of the ID with the relative weight of the consumed animal and plant products too. At the second stage of the experiment, men fully followed these models. At the end of experimental we compared the physical state results of men with the initial. The Results of the Research. The basis of experimental models were the differences between the days before the VPA and the usual ones: IP $-44,58 \%$, total physical activity $-21,31 \%$, relative weight of animal products $-14,65 \%$, relative weight of plant products $-10,62 \%$, the relative weight of all consumed products is $10,04 \%$. The basis of the model of the lifestyle of men in the forming experiment was the individual IP - Me = 1,66 steps per gram of consumed food during the day, which was observed by men on the eve of VPA. The method of correction of men's energy balance on the eve of VPA allowed to increase the number of classes per week of VPA, by 45,89\%; the number of VPA steps by $25,08 \%$; time taken to classes, by $11,41 \%$. Positive changes were observed in the physical condition of men too. Conclusions. The developed methodology of natural activation of VPA of men with lifestyle components, based on simulation of daily energy balance of the organism, proved to be effective. Increasing the body's energy reserves stimulates the desire for VPA classes the following day in the summer period.

Key words: lifestyle of men, high intensity physical activity, vigorous physical activity, model of nutrition, integral index of steps per gram of food.

Вступ. Серед багатьох факторів способу життя людини фізична активність (ФА) високої та середньої інтенсивності є найбільш ефективною для нормалізації серцево-судинної системи (ССС) і загального фізіологічного стану [12]. Проблема малорухомого способу життя чоловіків зрілого віку доволі актуальна через несприятливі наслідки для здоров'я. Сучасні умови життя чоловіків не дають змоги виконувати генетично запрограмовану важку фізичну роботу та бути фізично активними протягом доби [15]. Всесвітня організація охорони здоров'я та інші дослідження [5] вказують на недостатню ФА, особливо середньої й високої інтенсивності, у населення зрілого віку. Фізична активність високої інтенсивності (ФАВІ), із ЧСС вище 140 уд/хв, відрізняється від інших видів ФА більш тривалим процесом відновлення до 48 год [23]. Водночас організм споживає на 6-15 \% кисню більше, ніж у звичайних умовах [20], подовжуючи позитивний вплив на організм. Вправи на витривалість середньої та високої інтенсивності (понад 55 \% від максимальних) більше сприяють зниженню артеріального тиску в спокої ніж вправи низької інтенсивності [14]. Водночас ФАВІ вимагає попереднього досвіду та відповідного фізичного стану людини, спроможного енергетично забезпечити значні фізичні навантаження [4].

Фактори життєдіяльності людини забезпечують накопичення або витрати енергетичних запасів організму протягом 24 годин. Найбільш важливі 3 них ФА та харчування - функціонально різноспрямовані. Досліджувати вплив на фізичний стан людини кожного з них окремо у 24 годинному форматі неінформативно, оскільки всі компоненти енергетичного балансу взаємодіють один з одним, нівелюючи вплив один одного [13]. Виникає необхідність у пошуку інтегральних підходів до оцінки складових способу життя в добовому форматі [17] та активізації ФАВІ чоловіків із їх допомогою. Шляхи інтенсифікації ФА чоловіків зрілого віку треба шукати в оптимізації їх фізичного стану. Попередніми дослідженнями [4] доведено залежність ФАВІ чоловіків від змін оперативного стану ССС і загального фізіологічного стану організму на початку дня заняття. Останні дослідження $[18 ; 24]$ доводять залежність фізичного стану чоловіків зрілого віку без шкідливих звичок від ФА, харчування, сидячого способу життя, режиму відпочинку. Наші дослідження виявили найбільш інформативні фактори життєдіяльності чоловіків зрілого віку малорухомого способу життя - загальну фізичну активність та вагу спожитих продуктів у 24-годинному форматі [6]

В основу фізіологічних факторів життєдіяльності покладено теорію енергетичного гомеостазу організму. Одну частину факторів спрямовано на витрату енергії для адаптації та розвитку, іншу - на 
накопичення енергії й відновлення організму. Фізичний стан людини оптимізується при збалансуванні витрат і накопиченні енергії [10]. Збільшення витрати енергії в результаті ФА може бути більш ефективним для фізичного стану, ніж обмеження його накопичення споживанням їжі [19]. Особливо ефективні витрати енергії під час ФА з високою інтенсивністю ( $\geq 4$ днів / тиждень), порівняно 3 помірною [11]. Основним шляхом накопичення енергії в організмі $є$ харчування. Споживання енергоємної їжі має більший пріоритет у поведінці харчування людей зрілого віку, порівняно з впливом ФА [9]. Надмірне харчування, або споживання енергоємних продуктів, зумовлює накопичення енергетичних запасів, що призводить до збільшення ваги тіла, зростання АТ і хронічних захворювань [25]. Окрім енергоємності продуктів у накопиченні енергії, значення має швидкість їх катаболізму в організмі. Більш швидкому накопиченню енергії сприяє їжа рослинного походження (вуглеводні) [7]. Також сидячий спосіб життя, порівняно з активним, збільшуе енергетичний баланс майже на половину денної норми за однакових енергетичних дієт [21]. На сьогодні досліджений взаємозв'язок споживання деяких груп продуктів з інтенсивністю ФА чоловіків [22]. Зі збільшенням рівня ФА збільшується й кількість спожитих продуктів [8]. У попередніх наших дослідженнях [4] виявлено взаємозв'язок фізичного стану чоловіків 3 інтегральним показником кількості пройдених кроків за добу поділених на один спожитий грам їжі за добу. Цей взаємозв'язок виявився більш тісним, ніж окремо досліджений із ФА та харчуванням. Сезонні зміни навколишнього середовища стимулюють зміни гормональних процесів у людини [16]. Улітку активуються фізіологічні процеси в організмі людини. Збільшується ії ФА, покращується вегетативна регуляція серцево-судинної системи [1]. Також певні зміни відбуваються в харчуванні людини. Із метою оптимізації фізичного стану чоловіків для занять ФАВI, дослідження їх способу життя в літній період, буде актуальним. Перевірка ефективності моделі харчування та фізичної активності, їх інтегрального показника дасть змогу збільшити фізичну активність середньої й високої інтенсивності чоловіків.

Мета дослідження - аналіз ефективності методу природної активізації фізичної активності високої інтенсивності чоловіків молодого та середнього віку корекцією енергетичного балансу організму в літній сезон.

Матеріал і методи дослідження. Дослідження проведено на півдні України 2016 р. в літній період. Учасниками були 23 чоловіки віком 32-55 років, котрі ведуть здоровий спосіб життя та мають досвід самостійних занять ФАВІ у вигляді оздоровчого бігу, плавання, фітнесу. Усі учасники пройшли інструктаж на кафедрі медико-біологічних дисциплін Херсонського державного університету щодо дотримання необхідних процедурних стандартів у дослідженні свого фізичного стану, харчування та користування біорегістраторами.

Експеримент складався 3 двох частин - 21 день кожна. На першому етапі досліджували фізичний стан чоловіків, їхню фізична активність та харчування. Учасники експерименту вели звичайний спосіб життя та щоденно реєстрували показники свого фізичного стану вранці: вагу тіла (Soehnle 3 похибкою до 50 гр), ЧСС, АТ (напівавтоматичними тонометрами Contec 08A). Загальна вага спожитих продуктів класифікована за походженням - рослинна, тваринна, вимірювалися за день із точністю до 1 г. Фізична активність, у кількості пройдених кроків, ЧСС, фіксувалися цілодобово біорегістраторами Basis B1, Basis Peak. Вираховувався IП напередодні ФАВI.

За умовою на першому етапі експерименту заняття з ФАВІ чоловіки не планували заздалегідь, а займалися виключно під час виникнення індивідуального бажання.

На другому етапі чоловікам пропонували дотримуватися (оптимально через день) ІП співвідношення кількості пройдених кроків до кількості спожитих грамів їжі та відносної ваги спожитих продуктів тваринного й рослинного походження, визначених на першому етапі експерименту. Енергоємність продуктів контролювалася відсотковим співвідношенням ваги тваринних продуктів до відносної загальноспожитої ваги продуктів. Займатися ФАВІ чоловіки повинні були в разі виникнення відповідного бажання.

За щотижневими звітами учасників та результатами біорегістраторів, нами вираховувались індекс маси тіла (IMT) $\left(\kappa 2 / \mathrm{M}^{2}\right)$; індекс адаптаційного потенціалу серцево-судинної системи Баєвського (АПБ); ЧСС під час занять чоловіками ФАВI; ІП кількості пройдених кроків, поділених на кількість спожитих грамів продуктів за добу (крок/2) [4]. АПБ обчислювався в абсолютних одиницях (а.о.) за формулою:

АПБ $=0,011 \cdot$ ЧСС $+0,014 \cdot A T C+0,008 \cdot A T Д+0,014 \cdot B i \kappa+0,009 \cdot M T-, 009 \cdot Д T-0,273$,

де ЧСС- частота серцевих скорочень, $y \partial / x в$;

$A T C$ - артеріальний тиск систолічний, мм рт.cm;

АТД-артеріальний тиск діастолічний, мм pm. cm;

$M T$ - маса тіла, к2;

ДТ - довжина тіла, см;

Biк - вік обстежуваного, років [2]. 
ФАВІ чоловіків подавалася за тиждень. Загальна ФА без урахування ФАВІ в добовому форматі. Відсотки рахували за формулою

$x=(b-a): a * 100 \%$,

де $x$ - величина відсотка;

$a$ - попередній показник,

$b$ - наступний показник порівнюваної пари чисел.

Статистичне обрахування проводили застосуванням методів непараметричної статистики, оскільки результати не відповідали нормальному розподілу. Визначалися $95 \%$ інтерквартильний розмах $(I P)$, медіана $(\mathrm{Me})$. Порівняння показників між днями здійснювали за допомогою критерію знакових рангів Вілкоксона $з$ достовірністю $(p=0,05)$. Використовували програми EXEL та Statgraphics 16.

Результати дослідження. Порівняльний аналіз фізичного стану чоловіків (табл.1), відображений в IMT, та АПБ виявив надмірність у вазі досліджуваних при нормальному стані серцево-судинної системи. Порівняльний аналіз фізичного стану напередодні ФАВІ не мав достовірних відмінностей із повсякденними показниками. Фізична активність чоловіків напередодні була суттєво нижчою (21\%) від повсякденних показників, у той час як вага спожитих продуктів була більшою на $10 \%$. ІП у кількості кроків на один грам їжі показав ці відмінності у 44,58 \% меншою, ніж у повсякденні. Напередодні чоловіки робили 1,66 кроки на грам спожитої їжі, у звичайні дні - 2,4. При цьому вага тваринної їжі чоловіків напередодні була на 14,65 \%, більшою ніж щодня. Її частка в раціоні чоловіків також була більшою на 4,89 \%. Напередодні ФАВІ чоловіки споживали більше й рослинної їжі на 10,62 \%, хоча частка в раціоні не відрізнялася від повсякденної. Відсотковий склад їжі чоловіків не виходив за рекомендовані показники МО3 України 2013 р.

Таблиия 1

\section{Порівняння фізичного стану, фізичної активності, харчування та інтегрального показника чоловіків напередодні занять ФАВІ із повсякденними}

\begin{tabular}{|c|c|c|c|c|c|}
\hline \multirow[t]{2}{*}{$\begin{array}{l}\text { № } \\
\text { 3/II }\end{array}$} & \multirow[t]{2}{*}{ Показник } & $\begin{array}{c}\text { Напередодні ФАВI } \\
(\mathbf{n = 1 1 8 )}\end{array}$ & $\begin{array}{c}\text { Повсякденно } \\
(\mathrm{n}=473)\end{array}$ & \multirow{2}{*}{$\begin{array}{l}\text { Різниця, } \\
\%\end{array}$} & \multirow{2}{*}{$\begin{array}{l}\mathbf{W} \\
(\mathbf{p})\end{array}$} \\
\hline & & $\begin{array}{c}M e \\
(95 \% \text { IP) } \\
\end{array}$ & $\begin{array}{c}M e \\
(95 \% \text { IP) }\end{array}$ & & \\
\hline 1 & IMT, $\kappa 2 / M^{2}$ & $\begin{array}{c}27,01 \\
(24,31 ; 29,71)\end{array}$ & $\begin{array}{c}27,08 \\
(24,31 ; 29,69)\end{array}$ & 0,26 & $\begin{array}{l}21418 \\
>0,05\end{array}$ \\
\hline 2 & АПБ, a.o. & $\begin{array}{c}1,47 \\
(1,41 ; 1,53)\end{array}$ & $\begin{array}{c}1,52 \\
(1,47 ; 1,57) \\
\end{array}$ & 3,40 & $\begin{array}{l}39043 \\
>0,05 \\
\end{array}$ \\
\hline 3 & $\begin{array}{l}\text { ФА загальна, } \\
\text { кроків/добу }\end{array}$ & $\begin{array}{c}5460,10 \\
(4032,1 ; 6888,1)\end{array}$ & $\begin{array}{c}6623,41 \\
(5231,41 ; 8015,41)\end{array}$ & 21,31 & $\begin{array}{l}59271 \\
<0,05\end{array}$ \\
\hline 4 & $\begin{array}{l}\text { Відносна вага спожитої } \\
\text { їжі, г/кг }\end{array}$ & $\begin{array}{c}43,31 \\
(38,93 ; 47,69)\end{array}$ & $\begin{array}{c}38,96 \\
(34,75 ; 43,17)\end{array}$ & $-10,04$ & $\begin{array}{l}43429 \\
<0,05\end{array}$ \\
\hline 5 & ІПза добу, крок/2 & $\begin{array}{c}1,66 \\
(1,05 ; 2,27) \\
\end{array}$ & $\begin{array}{c}2,4 \\
(1,79 ; 3,01) \\
\end{array}$ & 44,58 & $\begin{array}{l}88582 \\
<0,05 \\
\end{array}$ \\
\hline 6 & $\begin{array}{l}\text { Відносна вага тваринної } \\
\text { іжі, г/кг }\end{array}$ & $\begin{array}{c}7,78 \\
(1,15: 14,41)\end{array}$ & $\begin{array}{c}6,64 \\
(1,56: 11,72)\end{array}$ & $-14,65$ & $\begin{array}{l}50341 \\
<0,05\end{array}$ \\
\hline 7 & Частка тваринної їжі, \% & $\begin{array}{c}19,42 \\
(11,69 ; 27,15)\end{array}$ & $\begin{array}{c}18,47 \\
(11,44 ; 25,5)\end{array}$ & $-4,89$ & $\begin{array}{l}40837 \\
<0,05 \\
\end{array}$ \\
\hline 8 & $\begin{array}{l}\text { Відносна вага рослинної } \\
\text { їжі, г/кг }\end{array}$ & $\begin{array}{c}33,72 \\
(20,39 ; 47,05)\end{array}$ & $\begin{array}{c}30,14 \\
(17,32 ; 42,96)\end{array}$ & $-10,62$ & $\begin{array}{l}60428 \\
<0,05 \\
\end{array}$ \\
\hline 9 & Частка рослинної їжі, \% & $\begin{array}{c}74,98 \\
(59,73 ; 90,23)\end{array}$ & $\begin{array}{c}75,31 \\
(60,41 ; 90,21)\end{array}$ & 0,44 & $\begin{array}{l}26124 \\
>0,05\end{array}$ \\
\hline
\end{tabular}

У результаті другого етапу експерименту, де чоловіки цілеспрямовано дотримувались IП, та індивідуально відносної ваги тваринних і рослинних продуктів визначеного першим етапом, відзначено такі зміни їхнього фізичного стану, фізичної активності, харчування (табл. 2).

IMT чоловіків на другому етапі становив $28,08 \mathrm{\kappa} 2 / \mathrm{m}^{2}$ - достовірних відмінностей із показниками повсякденних вимірів першого етапу експерименту не мав. Вага тіла $-87,97$ к2, достовірних змін не мала. ЧСС у спокої - 48,8 yd/xв - достовірно не відрізнялась. АТС у спокої на першому етапі експерименту - 114,58 мм pm. cm, на другому - на 5,54 \% достовірно менше (108,23 мм pm. cm.). АТД у спокої на першому етапі - 64,44 мм pm. cm., на другому - 61,77 мм pm. cm., без достовірних відмінностей. Комплексний показник ССС чоловіків - АПБ - на другому етапі експерименту дорівнював 1,55 a.o., 
що достовірно менше на 7,19 \% від показника першого етапу. IП Кї на другому етапі становив 2,32 кроків/2, що на 13,43 \% менше від показника першого етапу. Загальна ФА не змінилася на другому етапі експерименту (чоловіки проходили 5835,9 кроків/добу). Відносна вага спожитої їжі достовірно збільшилася (на 11,15 \%, до 30,91 г/кг). Добова частка тваринної їжі чоловіків достовірно зменшилась у другому етапі експерименту (на $8,82 \%$, до 23,77 \%). Частка рослинної їжі достовірно збільшилася (на $5,22 \%$ до 68,51 \%). ФАВІ на першому етапі становила 2897,85 кроків/тижд., на другому - зросла (на 34,64 \%, до 3901,01 кроків/тижд.). Кількість занять ФАВІ також збільшилося на $56 \%$ - із 1,75 раза/тижд., до 2,73 раза/тижд. на другому етапі. Час занять ФАВІ також збільшився на 18,86 \%, із 20,1 xв/тижд., до 23,89 хв/тижд. ЧСС під час занять ФАВІ достовірно не змінилася, на першому етапі - 141,61 yd/xв, на другому - 144,39 yd/xв.

Таблиия 2

\section{Порівняння фізичного стану та фізичної активності, чоловіків між етапами експерименту}

\begin{tabular}{|c|c|c|c|c|c|}
\hline \multirow[t]{2}{*}{$\begin{array}{l}\text { № } \\
\text { 3/II }\end{array}$} & \multirow[t]{2}{*}{ Показник } & $\begin{array}{c}\text { Перший етап } \\
\text { експерименту } \\
(\mathbf{n}=422)\end{array}$ & $\begin{array}{c}\text { Другий етап } \\
\text { експерименту } \\
(\mathbf{n}=\mathbf{4 1 5})\end{array}$ & \multirow{2}{*}{$\begin{array}{c}\text { Різниця, } \\
\%\end{array}$} & \multirow{2}{*}{$\begin{array}{l}\mathbf{W} \\
(\mathbf{p})\end{array}$} \\
\hline & & $\begin{array}{c}M e \\
(95 \% \text { IP) }\end{array}$ & $\begin{array}{c}M e \\
(95 \% \text { IP) }\end{array}$ & & \\
\hline 1 & IMT, $\kappa 2 / M^{2}$ & $\begin{array}{c}27,08 \\
(24,51 ; 29,65) \\
\end{array}$ & $\begin{array}{c}26,04 \\
(23,24 ; 28,84) \\
\end{array}$ & $-3,84$ & $\begin{array}{l}41254 \\
>0,05 \\
\end{array}$ \\
\hline 2 & АПБ, a.o. & $\begin{array}{c}1,59 \\
(1,48 ; 1,7)\end{array}$ & $\begin{array}{c}1,51 \\
(1,41 ; 1,6)\end{array}$ & $-5,03$ & $\begin{array}{l}66587 \\
<0,05\end{array}$ \\
\hline 3 & ФАВI, кроків/тижд. & $\begin{array}{c}4487,16 \\
(3146,41 ; 5827,91)\end{array}$ & $\begin{array}{c}5612,61 \\
(3927,61 ; 7297,61)\end{array}$ & 25,08 & $\begin{array}{l}72703 \\
<0,05\end{array}$ \\
\hline 4 & $\begin{array}{l}\text { Кількість занять ФАВІ, } \\
\text { разів/тижд. }\end{array}$ & $\begin{array}{c}2,07 \\
(1,51 ; 2,63)\end{array}$ & $\begin{array}{c}3,02 \\
(2,23 ; 3,81)\end{array}$ & 45,89 & $\begin{array}{c}809224 \\
<0,05\end{array}$ \\
\hline 5 & Час ФАВI, хв/тижд. & $\begin{array}{c}27,53 \\
(24,15 ; 30,91)\end{array}$ & $\begin{array}{c}30,67 \\
(26,39 ; 34,95)\end{array}$ & 11,41 & $\begin{array}{l}61495 \\
<0,05\end{array}$ \\
\hline 6 & ЧСС ФАВI, $y \partial / x \beta$ & $\begin{array}{c}141,06 \\
(133,51 ; 148,61)\end{array}$ & $\begin{array}{c}143,95 \\
(137,84 ; 150,06)\end{array}$ & 2,05 & $\begin{array}{l}34681 \\
>0,05\end{array}$ \\
\hline
\end{tabular}

Дискусія. За результатами першого етапу дослідження фізичної активності та харчування інтегральним способом у літній період уперше виявлено відмінність IП напередодні ФАВІ, порівняно 3 повсякденними значеннями. Порівняльний аналіз ФА та харчування підтвердив їх енергетичну різноспрямованість в енергетичному добовому балансі організму [17]. ФА була меншою, а відносна вага спожитої їжі - більшою. Відсоткова відмінність ІП напередодні ФАВІ чоловіків і повсякдень виявилася більшою, ніж окремо взяті показники ФА та харчування, підтвердивши інформативність ІП показника [4]. Застосування ІП дало можливість контролювати накопичення та витрати енергії організмом за кількістю пройдених кроків та вагою спожитих продуктів.

Збільшення спожитої чоловіками відносної ваги їжі напередодні ФАВІ підтверджує попереднє дослідження про вплив способу життя чоловіків на їхню фізичну активність високої інтенсивності в літній період [6]. Споживання основних груп продуктів i їх відсоткові співвідношення були відповідними до рекомендованих МОЗ України 2013 р., та Dietary Guidelines for Americans 2010, 2015. Частка тваринної їжі напередодні ФАВІ була достовірно більшою, ніж у звичайні дні. Схожий результат отримано попереднім нашим дослідженням [6], де вага спожитих чоловіками продуктів тваринного походження в літній час також була на 14,96 \% більшою.

За результатами другого етапу експерименту вперше досліджено запланований вплив IП у літній період на фізичний стан чоловіків. У результаті моделювання добового індивідуального IП з $\mathrm{Me}$ в 1,66 кроків на грам спожитої іжі з відносною нормою тваринної їжі в 7,78 г/кг зафіксовано достовірні позитивні зміни ФС чоловіків, що співвідносяться із даними [14] про зниження АТ, та нормалізацію ССС зі збільшенням ФА середньої й високої інтенсивності.

Уперше виявлено опосередкований вплив ІП на інтенсифікацію ФА чоловіків зрілого віку. Результатом змін їх ФС стало достовірне зростання кількості кроків, кількості занять, тривалості занять ФАВІ протягом тижня, узгоджуючись із даними попередніх досліджень [6], про залежність ФАВI чоловіків від їхнього способу життя. Інтенсифікація ФА відбулася внаслідок уперше змодельованого та застосованого серед чоловіків зрілого віку ІП.

Висновки. Розроблена методика природної активізації ФАВІ чоловіків складовими частинами способу життя на основі моделювання добового енергетичного балансу організму виявилась ефектив- 
ною. Збільшення енергетичних запасів організму стимулює бажання занять ФАВІ наступного дня. Накопичення енергетичних запасів чоловіків у літній період відбувалося за рахунок зниження загальної фізичної активності та збільшення спожитої їжі, безпосередньо продуктів тваринного походження.

У перспективі планується дослідження ефективності цієї методики в інших річних періодах.

\section{Джерела та література}

1. Агаджанян М. О., Полатайко Ю. О. Особливості реакції кардіо-респіраторної системи спортсменівплавців на дію гіпоксії у різні сезони року. Вісник Прикарпатського університету. Фізична культура. 2013. №18. С. 59-63.

2. Баевский Р. М. Донозологическая диагностика в оценке состояния здоров'я. Наука, 1993. С. 33-48.

3. Пришва О. Б. Вплив стану серцево-судинної системи чоловіків зрілого віку на їхню фізичну активність в осінній період. Фізичне виховання, спорт і культура здоров 'я у сучасному суспільстві. 2016. № 2(34). C. $38-45$.

4. Пришва О. Б. Інтегральний спосіб оцінювання впливу фізичної активності та харчування на фізичний стан чоловіків. Фізичне виховання, спорт і культура здоров'я у сучасному суспільстві. 2015. № 3(31). С. 156-159.

5. Пришва О. Б. Особливості фізичної активності чоловіків зрілого віку. Молодіжний науковий вісник Східноєвропейського національного університету імені Лесі Украӥнки. Фізичне виховання $і$ спорт. 2013. Вип. 10. С. 59-63.

6. Пришва О. Б. Особливості життєдіяльності чоловіків, які стимулюють фізичну активність високої інтенсивності в літній період. Фізичне виховання, спорт і культура здоров'я у сучасному суспільстві. 2016. № 4(36). C. 73-80.

7. Baker L. B., Nuccio R. P., at all. Acute effects of dietary constituents on motor skill and cognitive performance in athletes. Nutr Rev. 2014. 72. P. 790-802. doi.org/10.1111/nure.12157.

8. Beaulieu K., Hopkins M., Blundel J. E., at all. Do es habitual physical activity increase the sensitivity of the appetite control system? A systematic review. Sports Med. 2016. 46. P. 1897-919.

9. Beaulieu K., Hopkins M., Blundell J., at all. Impact of physical activity level and dietary fat content on passive overconsumption of energy in non-obese adults. International Journal of Behavioral Nutrition and Physical Activity. 2017. Vol. 14. № 1. P. 1.

10. Blundel J. E. Physical activity and appetite control. Can we close the energy gap? Nutr Bull. 2011. 36. P. 356-66.

11. Blundell J. E., Gibbons C., Caudwell P., at all.: Appetite control and energy balance. impact of exercise. Obes Rev. 2015. 16. P. 67-76.

12. Carson V., Tremblay, M. S., Chaput at all. Associations between sleep duration, sedentary time, physical activity and health indicators among Canadian children and youth using compositional analyses. Appl. Physiol. Nutr. Metab. 41. This issue. 10.1139/apnm.2016. 0026.

13. Chaput J. P., Carson V., Gray C. E., at all. Importance of all movement behaviors in a 24 hour period for overall health. Int J Environ Res Public Health. 2014. 11. P. 12575-81.

14. Cornelissen V. A., Smart N. A. Exercise training for blood pressure: a systematic review and metaanalysis. J Am Heart Assoc. 2013. 2:e 004473. doi.org/10.1161/JAHA.112.004473.

15. Dunstan D., Howard B., Healy G., at all. Too much sitting. A health hazard. Diabetes Res. Clin. Pract. 2012. 97. P. 368-376.

16. Gullo D., et al. Seasonal Variations in TSH Serum Levels in Athyreotic Patients under L Thyroxine Replacement Monotherapy. Clinical Endocrinology. 2017. Aug. 87(2). P. 207-215. doi: 10.1111/cen.13351.

17. Hall K. D., Heymsfield S. B., Kemnitz J. W., at all.: Energy balance and its components: implications for body weight regulation. Am J Clin Nutr. 2012. 95 (4). P. 989-994.

18. Halsey L. G., Huber J. W., Low T., at all. Do es consuming breakfast in fluence activity levels? An experiment into the effect of breakfast consumption on eating habits and energy expenditure. Public Health Nutr. 2012. 15(2). P. 238-45. doi.org/10.1017/S136898001100111X.

19. Hume D. J., Yokum S., Stice E. Low energy intake plus low energy expenditure (low energy flux), not energy surfeit, predicts future body fat gain. Am J Clin Nutr. 2016. 103. P. 1389-96.

20. La Forgia J., Withers R. T., Gore C. J. Effects of exercise intensity and duration on the excess post-exercise oxygen consumption. J Sports Sci. 2006. 24. P. 1247-64.

21. Murgatroyd P. R., Goldberg G. R., Leahy F. E., at all. Effects of inactivity and diet composition on human energy balance. Int J Obes Relat Metab Disord. 1999. 23. P. 1269-75.

22. Pryshva O., Tsos A. Interconnection of A Physical Activity of Mature Males with Their Diet. Research Journal of Pharmaceutical, Biological and Chemical Sciences (RJPBCS). Vol. 7. Issue 6. 2016 (NovemberDecember). http://www.ripbcs.com/pdf/2016_7(6)/[3].pdf.

23. Speakman J. R., Selman C. Physical activity and resting metabolic rate. Proc Nutr Soc. 2003. 62. P. 621-34.

24. Tremblay M. S., Carson V., Chaput J. P., et al. Canadian 24-hour movement guidelines for children and youth: an integration of physical activity, sedentary behaviour, and sleep. Appl Physiol Nutr Metab. 2016. 41 Suppl 3. P. 311-27.

25. Vernarelli J. A., Mitchell D. C., Rolls B. J., at all. Dietary energy density is associated with obesity and other biomarkers of chronic disease in US adults. Eur J Nutr. 2015. 54. P. 59-65. 


\section{References}

1. Ahadzhanian, M. O., Polataiko, Yu. O. (2013). Osoblyvosti reaktsii kardio-respiratornoi systemy sportsmenivplavtsiv na diiu hipoksii u rizni sezony roku. Visnyk Prykarpatskoho universytetu. Fizychna kultura, (18), 59-63.

2. Baevsky, R. M. (1993). Preclinical diagnosis in the evaluation of health status. Valeology: diagnostics, tools and practices for health. Sankt-Peterburg: Science.

3. Pryshva, O. (2016). Vplyv stanu sertsevo-sudynnoi systemy cholovikiv zriloho viku na yikhniu fizychnu aktyvnist v osinnii period. Fizychne vykhovannia, sport i kultura zdorovia u suchasnomu suspilstvi, 2(34), 38-45.

4. Pryshva, O. (2015). Intehralnyi sposib otsiniuvannia vplyvu fizychnoi aktyvnosti ta kharchuvannia na fizychnyi stan cholovikiv. Fizychne vykhovannia, sport i kultura zdorovia u suchasnomu suspilstvi, 3(31), 156-159.

5. Pryshva, O. (2013). Osoblyvosti fizychnoi aktyvnosti cholovikiv zriloho viku. Molodizhnyi naukovyi visnyk Skhidnoievropeiskoho natsionalnoho universytetu imeni Lesi Ukrainky. Fizychne vykhovannia i sport, (10), 59-63.

6. Pryshva, O. (2016). Osoblyvosti zhyttiediialnosti cholovikiv, yaki stymuliuiut fizychnu aktyvnist vysokoi intensyvnosti v litnii period. Fizychne vykhovannia, sport i kultura zdorovia u suchasnomu suspilstvi, 4(36), 73-80.

7. Baker, L. B., Nuccio, R. P., Jeuk end rup, A.E. (2014). Acute effects of dietary constituents on motor skill and cognitive performance in athletes. Nutr Rev, (72), 790-802. doi.org/10.1111/nure.12157

8. Beaulieu, K., Hopkins, M., Blundel, J. E., at all. (2016). Do es habitual physical activity increase the sensitivity of the appetite control system? A systematic review. Sports Med, (46), 1897-919.

9. Beaulieu, K., Hopkins, M., Blundell, J., at all. (2017) Impact of physical activity level and dietary fat content on passive overconsumption of energy in non-obese adults. International Journal of Behavioral Nutrition and Physical Activity, 14, (1),1.

10. Blundel, J. E. (2011). Physical activity and appetite control: Can we close the energy gap? Nutr Bull, (36), 356-66.

11. Blundell, J. E., Gibbons, C., Caudwell, P., at all. (2015). Appetite control and energy balance: impact of exercise. Obes Rev, (16), 67-76.

12. Carson, V., Tremblay, M. S., Chaput, at all. (2016). Associations between sleep duration, sedentary time, physical activity and health indicators among Canadian children and youth using compositional analyses. Appl. Physiol. Nutr. Metab? 41. This issue. 10.(1139), 0026.

13. Chaput, J. P., Carson, V., Gray, C. E., at all. (2014). Importance of all movement behaviors in a 24 hour period for overall health. Int J Environ Res Public Health, (11), 12575-81.

14. Cornelissen, V. A., Smart, N. A. (2013). Exercise training for blood pressure: a systematic review and metaanalysis. J Am Heart Assoc, (2),004473. doi.org/10.1161/JAHA.112.004473.

15. Dunstan, D., Howard, B., Healy, G., at all. (2012). Too much sitting. A health hazard. Diabetes Res. Clin. Pract, (97), 368-376.

16. Gullo, D., et al. (2017). Seasonal Variations in TSH Serum Levels in Athyreotic Patients under L Thyroxine Replacement Monotherapy. Clinical Endocrinology, 87(2), 207-215. doi.org/10.1111/cen.13351.

17. Hall, K. D., Heymsfield, S. B., Kemnitz, J. W., at all. (2012). Energy balance and its components: implications for body weight regulation. Am J Clin Nutr, 95 (4), 989-994

18. Halsey, L. G., Huber, J. W., Low, T. at all. (2012). Do es consuming breakfast in fluence activity levels? An experiment into the effect of breakfast consumption on eating habits and energy expenditure. Public Health Nutr, 15(2), 238-45. doi.org/10.1017/S136898001100111X.

19. Hume, D. J., Yokum, S., Stice, E. (2016). Low energy intake plus low energy expenditure (low energy flux), not energy surfeit, predicts future body fat gain. Am J Clin Nutr, (103), 1389-96.

20. La Forgia, J., Withers, R. T., Gore, C. J. (2006). Effects of exercise intensity and duration on the excess postexercise oxygen consumption. J Sports Sci, (24), 1247-64.

21. Murgatroyd, P. R., Goldberg, G. R., Leahy, F. E., at all. (1999).Effects of inactivity and diet composition on human energy balance. Int J Obes Relat Metab Disord, (23), 1269-75.

22. Pryshva, O., Tsos, A. (2016). Interconnection of A Physical Activity of Mature Males with Their Diet. Research Journal of Pharmaceutical, Biological and Chemical Sciences, 7(6). :http://www.rjpbcs.com/ pdf/2016_7(6)/[3].pdf.

23. Speakman, J. R., Selman, C., (2003). Physical activity and resting metabolic rate. Proc Nutr Soc, (62):621-34

24. Tremblay, M. S., Carson, V., Chaput, J. P., et al. (2016). Canadian 24-hour movement guidelines for children and youth: an integration of physical activity, sedentary behaviour, and sleep. Appl Physiol Nutr Metab, 41(3), 311-27.

25. Vernarelli, J. A., Mitchell, D. C., Rolls, B. J., at all. (2015). Dietary energy density is associated with obesity and other biomarkers of chronic disease in US adults. Eur J Nutr, (54), 59-65.

Стаття надійшла до редакції 02.10.2019 p. 